\title{
TERRORISM AND THE WORLD ECONOMY
}

\author{
Alberto Abadie - Harvard University and NBER \\ Javier Gardeazabal - University of the Basque Country
}

October 2005

\begin{abstract}
It has been argued that terrorism should not have a large effect on economic activity, because terrorist attacks destroy only a small fraction of the stock of capital of a country (see, e.g., Becker and Murphy, 2001). In contrast, empirical estimates of the consequences of terrorism typically suggest large effects on economic outcomes (see, e.g., Abadie and Gardeazabal, 2003). The main theme of this article is that mobility of productive capital in an open economy may account for much of the difference between the direct and the equilibrium impact of terrorism. We use a simple economic model to show that terrorism may have a large impact on the allocation of productive capital across countries, even if it represents a small fraction of the overall economic risk. The model emphasizes that, in addition to increasing uncertainty, terrorism reduces the expected return to investment. As a result, changes in the intensity of terrorism may cause large movements of capital across countries if the world economy is sufficiently open, so international investors are able to diversify other types of country risks. Using a unique dataset on terrorism and other country risks, we find that, in accordance with the predictions of the model, higher levels of terrorist risks are associated with lower levels of net foreign direct investment positions, even after controlling for other types of country risks. A standard deviation increase in the terrorist risk induces a fall in the net foreign direct investment position of about 5 percent of GDP. The magnitude of the estimated effect is large, which suggests that the "open-economy channel" impact of terrorism may be substantial.
\end{abstract}

Alberto Abadie, John F. Kennedy School of Government, 79 John F. Kennedy Street, Cambridge MA 02138, USA. E-mail: alberto_abadie@harvard.edu. Javier Gardeazabal, Dpto. Fundamentos del Análisis Económico, Avda. Lehendakari Aguirre 83, 48015 Bilbao, Spain. E-mail: jepgamaj@bs.ehu.es. We thank Pol Antràs, Jeff Frankel, Dani Rodrik, Todd Sandler, Jaume Ventura, Andrés Velasco, Richard Zeckhauser and seminar participants at the 2005 NBER Summer Institute for very useful comments. Erik Garrison provided expert research assistance. Financial support for this research was generously provided through NSF grant SES-0350645 (Abadie), Spanish Ministry of Science and Technology grant SEC2003-04826 and University of the Basque Country grant 35.321-13511 (Gardeazabal). 


\section{INTRODUCTION}

This paper analyzes the effects of terrorism in an integrated world economy. From an economic standpoint, terrorism has been described to have four main effects (see, e.g., US Congress, Joint Economic Committee, 2002). First, the capital stock (human and physical) of a country is reduced as a result of terrorist attacks. Second, the terrorist threat induces higher levels of uncertainty. Third, terrorism promotes increases in counter-terrorism expenditures, drawing resources from productive sectors for use in security. Fourth, terrorism is known to affect negatively specific industries such as tourism. ${ }^{1}$ However, this classification does not include the potential effects of increased terrorist threats in an open economy. In this article, we use a stylized macroeconomic model of the world economy and international data on terrorism and the stock of foreign direct investment (FDI) assets and liabilities to study the economic effects of terrorism in an integrated world economy.

The motivation to study the impact of terrorism in an open world economy is the following. It has been documented that the direct impact of terrorist attacks on productive capital is relatively modest. This seems to be true even for events of catastrophic terrorism. For example, Becker and Murphy (2001) estimated that the September 11th terrorist attacks resulted in a loss of 0.06 percent of the total productive assets of the US economy. In consequence, after taking into account the four channels mentioned in the previous paragraph, some authors have argued that terrorism is unlikely to exert a significant influence on economic activity in the long-run. The calculations in Becker and Murphy (2001) bound the long-run effect of the September 11th attacks to 0.3 percent of GDP (see also IMF, 2001a and OECD, 2001). ${ }^{2}$

In contrast, reduced-form estimates of the economic effects of terrorism typically suggest much larger effects. For example, in our previous study of the impact of terrorism in the Basque Country, we find a 10 percent drop in per capita GDP which emerges during a period of two decades and that is attributable to the terrorist conflict (Abadie and

\footnotetext{
${ }^{1}$ See Enders, Sandler, and Parise (1992) on the effect of terrorism on tourism.

${ }^{2}$ In a more recent paper, Becker and Rubinstein (2004) have argued that terrorism risk may have a large economic impact if the fear of terrorism affects individual utility in each state of nature.
} 
Gardeazabal, 2003). Chen and Siems (2004), Enders and Sandler (1996), Frey, Luechinger, and Stutzer (2004a), and Pshisva and Suarez (2004) similarly find large effects of terrorism on economic variables. ${ }^{3}$ However, as noted by Becker and Rubinstein (2004), the question of why terrorism may have a large effect on the economy, even if it represents a small fraction of the total economic risk, has attracted much less attention in the academic literature.

The main theme of this paper is that mobility of productive factors in an open economy may account for much of the difference between the direct effect and the equilibrium effect of terrorism on the economy. If terrorism is a local phenomenon, capital will tend to flow to destinations without a terrorist threat, reducing net foreign investment in the economies affected by terrorism. Even if terrorism is a global threat, international investment will respond to differences in the expected intensity of terrorism across countries. In fact, because the optimal allocation of capital across countries depends not only on the level of terrorism but also on other country factors that affect the distributions of the returns to capital, variations in the overall level of terrorism in the world may induce a re-allocation of capital across countries even if the relative intensity of terrorist risk across countries remains unchanged.

The amounts of foreign direct investment in the U.S. before and after the September 11th attacks provide some suggestive evidence of the open-economy channel of terrorism. In the year 2000, the year before the terrorist attacks, foreign direct investment inflows represented about 15.8 percent of the Gross Fixed Capital Formation in the U.S. This figure decreased to only 1.5 percent in 2003, two years after the attacks. Conversely, foreign direct investment outflows from the U.S. increased from about 7.2 percent of the Gross Fixed Capital Formation for the U.S. in 2000 to 7.5 percent in 2003 (see UNCTAD, 2004). Of course, not all this drop in FDI in the U.S. can be attributed to the effect of the September 11th attacks. As of September 2001 foreign direct investment inflows had fallen from its 2000 peak not only in the U.S. but also in other developed economies (see UNCTAD, 2002). These figures, however, motivate the question of to which extent an

\footnotetext{
${ }^{3}$ Frey, Luechinger, and Stutzer (2004b) surveys the existing research on the economic impact of terrorism.
} 
increase in the perceived level of terrorism was responsible for the drop in FDI in the U.S. that followed the events of September 11th.

Surveys of international corporate investors provide direct evidence of the importance of terrorism on foreign investment. Corporate investors rate terrorism as one of the most important factors influencing their foreign direct investment decisions (see Global Business Policy Council, 2004).

To illustrate the importance of the "open-economy channel" of terrorism we use a stochastic version of the $A K$ endogenous growth model (see, e.g., Obtsfeld, 1994, and Turnovsky, 1997). We extend this model by introducing terrorism as a stochastic Poisson process, with events that destroy some fraction of the capital stock of a country.

The model emphasizes that beyond increasing uncertainty, terrorism reduces expected return to investment. As a result, changes in the intensity of terrorism have an ambiguous effect on the overall investment position of the world (investments over wealth), but they may cause large movements of capital across countries if the world economy is sufficiently open, so international investors are diversified against other types of country risks.

One of the predictions of our model is that, like any other risk, terrorism should affect the stock of international investment in any particular country. Therefore, it is possible to obtain empirical evidence on the "open-economy channel" of terrorism by looking at the relationship between net foreign investment and terrorism in the cross-section of countries, as long as we account for other factors that affect international investment positions, particularly other country risks which may be correlated with terrorism levels. For this purpose, we use a unique international dataset on terrorism risk and other types of country risks. We find that terrorism has a negative and sizeable impact on foreign investment positions.

Enders and Sandler (1996) have also studied the effect of terrorism on capital flows across countries. Using vector autoregression methods, these authors estimated a negative 13.5 percent effect of terrorism on foreign direct investment for Spain (for the period 197691) and a negative 11.9 percent effect for Greece (for the period 1975-91). Our empirical results for a cross-section of countries corroborate and provide external validity to the 
results of Enders and Sandler.

The rest of the article is organized as follows. In Section 2, we built a simple model that illustrates why terrorism may have a large effect on net foreign investment in an open world economy even if terrorism induces only a small fraction of the total economic risk. Section 3 describes the data set. Section 4 provides empirical evidence on the effect of terrorism on foreign direct investment. Section 5 concludes.

\section{A Simple Model of Catastrophic Terrorism}

\subsection{The Model}

Consider a two-country economy with terrorism and perfect capital mobility across countries. We will refer to one of the countries as the "domestic economy" and to the other as the "foreign economy". The world population consists of a continuum of identical and infinitely-lived agents with mass equal to one, who are equally distributed among the two countries. At each point in time, $t$, agents decide how much to consume, $C(t)$, and which fraction, $v(t)$, of the capital to devote to production in the domestic economy (with a fraction $1-v(t)$ devoted to production in the foreign economy). If the fraction of capital devoted to a country changes, this change generates a flow of investment from one country to the other.

As in Obstfeld (1994) and Turnovsky (1997), we assume that production in the domestic economy is given by a stochastic $A K$ technology:

$$
d Y(t)=\alpha v(t) K(t) d t+\sigma_{W} v(t) K(t) d W(t)
$$

where $d Y(t)$ is output, $K(t)$ is the world stock of capital (physical and human), and $W(t$ ) is a Wiener process, whose innovations capture domestic productivity shocks.

The assumptions of constant returns to scale and perfect capital mobility across countries are not totally innocuous. These assumptions increase the sensitivity of the allocation of capital across countries to differences in the distributions of the return to capital between countries. The assumptions of constant returns to scale and perfect capital mobility 
across countries are likely to be violated in the short run. However, these assumptions are consistent with the long run trends in the allocation of capital across countries. ${ }^{4}$

Terrorist attacks are captured in this model as innovations from a Poisson process, $P(t)$ with rate $\lambda$, which destroy a fraction $\delta$ of the stock of capital allocated by every investor to the domestic economy, with $0 \leq \delta \leq 1$. After the direct impact of terrorism is taken into account, the return to capital in the domestic economy is governed by a jump-diffusion:

$$
d R(t)=\frac{d Y(t)-\delta v(t) K(t) d P(t)}{v(t) K(t)}=\alpha d t+\sigma_{W} d W(t)-\delta d P(t)
$$

By the properties of Wiener and Poisson processes, the expectation and variance of the return to capital in the domestic economy are:

$$
E[d R(t)]=(\alpha-\lambda \delta) d t
$$

and

$$
\operatorname{var}(d R(t))=\left(\sigma_{W}^{2}+\lambda \delta^{2}\right) d t
$$

Therefore, an increase in the intensity of domestic terrorism, $\lambda$, reduces the expected return to capital in the domestic economy and increases its variance.

Production and terrorism follow analogous processes in the foreign economy, for which we will use the notation: $\alpha^{*}, \sigma_{W}^{*}, \delta^{*}, \lambda^{*}, d W^{*}(t)$, and $d P^{*}(t)$.

Agents derive instantaneous utility from consumption, $C(t)$, through a constant relative risk aversion utility function: $u(c)=\left(c^{1-\gamma}-1\right) /(1-\gamma)$, with $\gamma>0$ and $c>0$ (taking the limiting form $u(c)=\ln (c)$, for $\gamma=1$ ). The parameter $\gamma$ is the Arrow-Pratt measure of relative risk aversion, $\gamma=-c u^{\prime \prime}(c) / u^{\prime}(c)$.

Agents choose $C(t)$ and $v(t)$ to maximize lifetime discounted utility, subject to the law of motion for capital. Because all agents have the same preferences and investment possibilities, regardless of how ownership of productive capital is distributed, the equilibrium

\footnotetext{
${ }^{4}$ McGrattan (1998) and Li (2002) present evidence that long-run trends in investment and growth are consistent with the predictions of the $A K$ model. More importantly for the purpose of this article, Kraay and Ventura $(2000,2002)$ show that the observed long-run patterns in the allocation of capital across countries are consistent with weak diminishing returns to capital.
} 
in the world economy is given by the solution of the utility maximization problem for a representative agent:

$$
\begin{aligned}
& \max E \quad\left[\int_{0}^{\infty} \mathrm{e}^{-\beta t} \frac{C(t)^{1-\gamma}-1}{1-\gamma} d t\right] \\
& \text { s.t. } \quad d K(t)=\left(\alpha v(t) K(t)+\alpha^{*}(1-v(t)) K(t)-C(t)\right) d t \\
&+\sigma_{W} v(t) K(t) d W(t)+\sigma_{W}^{*}(1-v(t)) K(t) d W^{*}(t) \\
&-\delta v(t) K(t) d P(t)-\delta^{*}(1-v(t)) K(t) d P^{*}(t) \\
& 0 \leq C(t) \leq K(t), K(t) \geq 0, K(0)=K_{0}, 0 \leq v(t) \leq 1 .
\end{aligned}
$$

The Hamilton-Jacobi-Bellman equation for this problem is:

$$
\begin{aligned}
\beta V(k)=\max _{c, v}\left\{\frac{c^{1-\gamma}-1}{1-\gamma}\right. & +\frac{\partial V(k)}{\partial k}\left(\alpha v k+\alpha^{*}(1-v) k-c\right)+\frac{1}{2} \frac{\partial^{2} V(k)}{\partial k^{2}}\left(\sigma_{W}^{2} v^{2} k^{2}+\sigma_{W}^{* 2}(1-v)^{2} k^{2}\right) \\
& \left.+\lambda(V(k-\delta v k)-V(k))+\lambda^{*}\left(V\left(k-\delta^{*}(1-v) k\right)-V(k)\right)\right\},
\end{aligned}
$$

for some function, $V(k)$. (See appendix for a detailed derivation of the solution.) Solving this differential equation we obtain the optimal consumption plan:

$$
\begin{aligned}
C(t)=\frac{1}{\gamma}(\beta+(\gamma-1)(\alpha \widehat{v} & \left.+\alpha^{*}(1-\widehat{v})\right)-\frac{1}{2} \gamma(\gamma-1)\left(\sigma_{W}^{2} \widehat{v}^{2}+\sigma_{W}^{* 2}(1-\widehat{v})^{2}\right) \\
& \left.-\lambda\left[(1-\delta \widehat{v})^{1-\gamma}-1\right]-\lambda^{*}\left[\left(1-\delta^{*}(1-\widehat{v})\right)^{1-\gamma}-1\right]\right) K(t),
\end{aligned}
$$

where $\widehat{v}$ is the optimal share of world capital invested in the domestic economy, which is implicitly determined by:

$$
\left(\alpha-\alpha^{*}\right)-\gamma\left(\sigma_{W}^{2} \widehat{v}-\sigma_{W}^{* 2}(1-\widehat{v})\right)-\lambda \delta(1-\delta \widehat{v})^{-\gamma}+\lambda^{*} \delta^{*}\left(1-\delta^{*}(1-\widehat{v})\right)^{-\gamma}=0
$$

Notice that equation (3) implies that the optimal share of capital invested in the domestic economy is time-invariant, for any given value of the parameters of the model.

Let $\theta$ be the fraction of the world's productive capital owned by residents of the domestic economy. Domestic consumption and wealth are equal to $\theta C(t)$ and $\theta K(t)$ respectively. Similarly, foreign consumption and wealth are equal to $(1-\theta) C(t)$ and $(1-\theta) K(t)$. In this economy, domestic and foreign residents hold the same portfolio of assets, a share in 
the world portfolio. Hence, the distribution of consumption and wealth among countries is time-invariant. However, production depends on the allocation of capital across countries. Therefore, the distribution of the stock of capital between countries depends on the intensity of terrorism in both countries and the other parameters of the model.

\subsection{The Effects of Terrorism}

In this economy, terrorism affects capital accumulation through three different channels. First, terrorist events directly destroy part of the capital stock of a country, $\delta$. As explained above, in practice, the quantitative importance of this effect seems to be small.

Second, terrorism changes the process that determines the return to capital, affecting the overall investment position of the individuals in the world economy. However, the direction of this second effect is theoretically ambiguous. In the absence of a terrorist attack, every unit of capital is either consumed or saved as productive capital. Let $\pi_{C}=C(t) / K(t)$ be the consumption-wealth ratio. Differentiating $\pi_{C}$ with respect to $\lambda$ and using equation (3) we obtain:

$$
\frac{d \pi_{C}}{d \lambda}=\frac{1}{\gamma}\left[1-(1-\delta \widehat{v})^{1-\gamma}\right] .
$$

As shown in equation (4), terrorism increases the consumption-wealth ratio if $\gamma<1$ and decreases the consumption-wealth ratio if $\gamma>1$. The reason is that terrorism reduces the average return to investment and increases its variance. As a result, terrorism induces a negative income effect and a positive substitution effect on consumption. The negative income effect dominates when $\gamma>1$. However, the positive substitution effect dominates for individuals with risk aversion smaller than that given by logarithmic utility. (The substitution and income effects are derived in the appendix.)

Finally, and most importantly for the purpose of this article, terrorism affects the allocation of productive capital across countries. The international investment position of the domestic economy is determined by the fraction of the world's capital owned by residents of the domestic economy, $\theta$, and the fraction of the world's capital allocated to production in the domestic economy, $\widehat{v}$. In the notation of the model, the international 
investment position of the domestic economy is equal to foreign holdings of domestic capital $(1-\theta) \widehat{v} K(t)$ minus domestic holdings of foreign capital $\theta(1-\widehat{v}) K(t)$. Therefore, the international investment position of the domestic economy (normalized by the amount of productive capital allocated to the domestic economy, $\widehat{v} K(t))$ is equal to $1-\theta / \widehat{v}$. If $\widehat{v}>\theta$, net foreign investment is positive in the domestic economy and negative in the foreign economy. Conversely, if $\widehat{v}<\theta$, net foreign investment is positive in the foreign economy and negative in the domestic economy.

To investigate the effect of terrorism on net foreign investment, we differentiate equation (3) with respect to $\lambda$ :

$$
\frac{d \widehat{v}}{d \lambda}=-\frac{\delta(1-\delta \widehat{v})^{-\gamma}}{\gamma\left(\sigma_{W}^{2}+\sigma_{W}^{* 2}\right)+\lambda \delta^{2} \gamma(1-\delta \widehat{v})^{-\gamma-1}+\lambda^{*} \delta^{* 2} \gamma\left(1-\delta^{*}(1-\widehat{v})\right)^{-\gamma-1}}<0 .
$$

In the model, terrorism has an unambiguously negative effect on $\widehat{v}$. Notably, the magnitude of this effect is unbounded. In this simple two-country model, the effect of terrorism on capital allocation across countries will be small if the direct impact of terrorist attacks, represented by $\delta$, is small, as long as the degree of risk aversion of international investors, $\gamma$, is relatively large. However, if international investors are close to risk neutrality (if $\gamma$ is close to zero), terrorist risk will have a large effect on the allocation of capital across countries. The reason is that, in contrast to smooth risk, an increase in the intensity of catastrophic terrorism not only increases the variance of the return to investment, it also decreases its average. Investors with low levels of risk aversion have no reason to diversify country risk, and react abruptly to relative changes in the intensity of terrorism.

This may be an important consideration in practice. If international investors are sufficiently diversified, they will have no reason to invest in countries with relatively high levels of terrorist risk (if it is difficult to diversify terrorist risk locally). To illustrate this point, suppose that the world economy consists of $N$ economies (the domestic economy plus $N-1$ foreign countries). To simplify the exposition, assume that only the domestic economy is exposed to terrorism and that in the absence of a terrorist shock production in country $i(i=1, \ldots, N)$ is given by the stochastic process

$$
\alpha v_{i}(t) K(t)+\sigma v_{i}(t) K(t) d W_{i}(t)
$$


where $W_{1}, \ldots, W_{N}$ are independent Wiener processes. As before, terrorism in the domestic economy is described by a Poisson process with coefficients $(\lambda, \delta)$. In this scenario, the fraction of world's capital invested in the domestic economy, $\widehat{v}$, is given by:

$$
-\gamma \sigma^{2}\left(\frac{N \widehat{v}-1}{N-1}\right)-\lambda \delta(1-\delta \widehat{v})^{-\gamma}=0 .
$$

If there is no terrorism $(\lambda=0)$, then the domestic economy receives a fraction $1 / N$ of world's capital. If there is terrorism in the domestic economy but not in the rest of the world $(\lambda>0)$, then $\widehat{v}$ will be smaller than $1 / N$. Moreover, notice that $\widehat{v} /(1 / N) \leq \max \{1-$ $\left.\left(\lambda \delta / \gamma \sigma^{2}\right)(N-1), 0\right\}$, so for any given value of $\gamma$, the ratio $\widehat{v} /(1 / N)$ will be small when the number of countries, $N$, is large. The reason is that when investment can be placed in many countries international investors are able to diversify risk without allocating capital to countries with a higher relative risk of terrorism and therefore with a lower expected return.

Figure 1 shows how diversification opportunities accentuate the impact of terrorism on net foreign investments. The left hand side panel of Figure 1 shows the value of $\widehat{v} /(1 / N)$ as a function of the number of countries $N$, for $\gamma=1$. The three series on the graph represent three different values $\left(100,200\right.$, and 400) for $\sigma /\left(\lambda^{1 / 2} \delta\right)$, which is the ratio of the standard deviation of non-terrorist risk over the standard deviation of terrorist risk. The values of $\lambda$ and $\delta$ are set to 0.10 and 0.0005 , respectively. The right hand side panel of Figure 1 shows the same graph for $\gamma=10$, a substantially higher degree of risk aversion. The value of $\widehat{v} /(1 / N)$ decreases rapidly with $N$ in all cases. In the case of $\gamma=1$ and $\sigma /\left(\lambda^{1 / 2} \delta\right)=100$, there is no investment in the domestic economy if the world consists of more than a few countries. Even in the case of $\gamma=10$ and $\sigma /\left(\lambda^{1 / 2} \delta\right)=400, \widehat{v} /(1 / N)$ is about $10 \%$ lower than one (the value that it would take in the absence of terrorism) with 80 countries. Figure 1 shows that, even if terrorist risk is only a small fraction of total economic risk, it may still have a large economic impact in an open economy. 


\subsection{Model interpretation AND EMPIRICAL DESIGN}

In the empirical section of this article, we use a measure of terrorism risk at the country level produced by an international risk rating agency to study the effect of terrorism on net foreign direct investment positions.

We choose to investigate the effect of terrorism on international investment positions rather than on capital flows for various reasons. First, as explained above, the equilibrium portrayed by our model can be interpreted as a description of the long-run relationship between terrorism risk and international investment positions at the country level. Because the model lacks transitional dynamics, it cannot effectively describe short-run capital movements in response to variations in the intensity of terrorism. Moreover, because diminishing returns to capital and adjustment costs are expected to be substantial in the short run, a study of the effects of changes in the intensity of terrorism on short-run capital movements will underestimate the long-run impact of terrorism.

In addition, while measures of terrorism risk in the cross-section of countries exist, we currently lack adequate longitudinal risk data to conduct a direct study of capital flows. In principle, short term variations in terrorist risk levels could be used in a fixed-effects model to estimate the effect of terrorism on foreign direct investment while controlling for unobserved determinants of foreign direct investment that are fixed in the short run. In practice, however, the use of longitudinal data on terrorist risk would be extremely problematic. On the one hand terrorist risk does not seem to display much short-term variation. ${ }^{5}$ On the other hand, it may be difficult to establish the exact timing of the impact of a change in terrorist risk on foreign direct investment. International investors may perceive short term changes in terrorist risk before or after the risk rating data indicate, and the response of foreign direct investment to short term changes in the level of terrorist risk may be attenuated in the short run by the irreversible nature of direct investment.

Finally, notice that short-term longitudinal data on terrorist events or casualties may

\footnotetext{
${ }^{5}$ For example, the terrorist risk index produced every year since 1995 by the Economist Intelligence Unit for a set of 60 countries did not report any change in the level of terrorist threat for any country until the year 2001.
} 
not be adequate to estimate the impact of terrorism risk in a fixed effects model. The reason is that in most countries terrorist incidents are low-probability events. Therefore, shortterm variation in the level of terrorist activity may be large even if the underlying level of terrorist risk experiences little variation. In other words, terrorist events or casualties are noisy measures of the latent level of terrorist risk. As a result, the regression coefficients on variables measuring terrorist events or casualties will be biased towards zero. Time differencing the data in a fixed effects model is known to exacerbate errors-in-variables biases (Griliches and Hausman, 1986). In addition, the use of direct indicators of terrorist events or casualties present other problems, which are described in Section 3.

Of course, the main disadvantage of using cross-sectional data is the potential for omitted variable bias. To address this problem we perform a careful sensitivity analysis and demonstrate that the results of the empirical section are robust to many different specifications.

As explained in the following section, country level data on foreign direct investment are readily available for 196 countries and the sample period considered in the empirical section. The same is not true yet for debt and portfolio investment. Thus, we restrict our attention to direct investment, and do not consider debt and portfolio investment. A more substantive reason for dealing only with foreign direct investment is that debt and portfolio investment are heavily affected by financial crises, the degree of development of the countries' financial institutions, and complicated capital control schemes.

\section{The DATA}

The model we developed in the previous section predicts that, even if terrorist attacks destroy only a small fraction of the productive capital of a country, increases in terrorist risk may greatly affect the allocation of international investment across countries. In the next section, we use a unique dataset on terrorist and other country risks to quantify the impact of terrorism on net foreign direct investment (net FDI) positions.

The evidence presented below uses data on the net stock of FDI from a cross-section 
of countries. Data on FDI stocks come from the United Nations Conference on Trade And Development (UNCTAD, 2004). The UNCTAD database provides information on FDI stocks in the year 2003 for 196 countries and territories. Net FDI positions are measured as direct investment liabilities minus direct investment assets normalized by GDP. ${ }^{6}$ We will sometimes refer to the net FDI position as a fraction of GDP simply as net FDI positions.

Our measure of country terrorism risk is the World Markets Research Centre's Global Terrorism Index (GTI). The Global Terrorism Index seems to be the first comprehensive attempt to measure globally the risk from terrorist attacks at the country level. The Global Terrorism Index covers 186 countries and territories for the period 2003/4. The Global Terrorism Index combines expert ratings of the motivation, presence, scale, efficacy, and prevention of terrorism at the country level. ${ }^{7}$

Previous empirical studies on terrorism have used two types of indicators of terrorist activity: the number of terrorist incidents and the number of casualties. These measures may suffer from several drawbacks. As noted by Frey, Luechinger and Stutzer (2004b), the number of attacks and casualties collected from official statistics or from the media may underestimate the actual number of casualties caused by terrorism. In addition, data on terrorist incidents group together attacks of different magnitude and significance. Perhaps more importantly, in the risk-based analysis of this paper, terrorism is not simply a history of violence, but a latent variable representing the uncertainty created by the possibility of future terrorist attacks. Statistics on the number of terrorist events or casualties may not fully reflect the level of terrorism perceived by international investors.

Terrorist risk ratings, like the GTI, do not suffer from these drawbacks and incorporate information that relate to risk but are not reflected in casualties, like motivation of terrorists or prevention by the authorities. Moreover, because risk ratings are commonly used by international investors to evaluate specific country risks, they have the advantage

\footnotetext{
${ }^{6}$ FDI assets (liabilities), are defined as the value of capital and reserves, including retained profits, invested in a foreing (the domestic) economy attributable to the parent enterprise, plus the net indebtedness of affiliates to the parent enterprise resident in the domestic (a foreign) economy. Data on FDI stocks is at book value or historical cost, reflecting prices at the time when the investment was made.

${ }^{7}$ See World Markets Research Centre (2003) for further information on the Global Terrorism Index.
} 
of directly reflecting one of the most important channels through which information about terrorism risk is revealed to international investors. Consequently, terrorism risk ratings are particularly relevant as a measure of terrorism risk to evaluate the effect of terrorism on international investment. A disadvantage of terrorism risk ratings is that they provide only a summary measure of an intrinsically complex phenomenon.

Like any other risk, terrorism should depress the stock of international investment in any particular country. Therefore, empirical evidence on the "open-economy channel" of terrorism can be obtained using a cross-section of countries. In our regressions, we measure the amount of variance of net FDI stock (normalized by the country GDP) explained by terrorist risk. Because international investors take into account other types of risk factors such as the overall political, legal, and security environments of the target country, this exercise must acknowledge sources of risk other than terrorism. As we will show below, these other risk factors correlate with terrorist risk. Therefore, it is important to control in our regressions for other risk factors which may also affect foreign investment. Risk rating data allow us to do exactly this. We include in our regressions a country risk index also produced by the World Markets Research Centre (WMRC). The WMRC Country Risk Index combines six risk factors (political, economic, legal, tax, operational, and security) into an overall country risk index.

As explained in the previous section, the net foreign investment position of a country is affected by the fraction of world's productive capital owned by the residents of that country. Because rich countries have higher per capita levels of capital, we include in our regressions the countries' levels of GDP per capita as an explanatory variable (these data come from the World Bank, 2004).

Of course, the stock of foreign investment of a country depends crucially on the degree of the country's openness to capital mobility. To measure the degree of openness of a country to foreign capital we use the index of capital flows and foreign investment restrictions published as a factor of the Index of Economic Freedom by The Heritage Foundation and The Wall Street Journal (Miles et al, 2004). ${ }^{8}$

\footnotetext{
${ }^{8}$ Available at: http://www.heritage.org/research/features/index/.
} 
Finally, regional factors not accounted for by the country risk ratings or the other explanatory variables may also influence the investment position of a country. To control for these effects, we include regional dummies in many of the regressions reported below.

\section{EMPIRICAL ANALYSIS}

\subsection{Main Results}

This section assesses the effect of terrorism on foreign direct investment positions in an open world economy. Some of the 186 countries included in the WMRC Global Terrorism Index impose severe restrictions on foreign direct investment, hence they are excluded because they do not comply with the open market environment considered in this article. For this reason we use the classification published by the International Monetary Fund (IMF, 2001b) to restrict our sample to 110 countries with no restrictions on FDI repatriations and available data on FDI assets and liabilities as well as GDP. Additionally, when a measure of openness to FDI is included in the regression the sample is further restricted to 98 countries. Table B1 in appendix B lists the countries in the full 186-country sample and subsamples.

Table 1 describes the terrorist and country risk data for the 186-country full sample and the 110-country regression sample. Among country risk factors, security exhibits the highest correlation with terrorist risk (GTI). Part of the correlation between the terrorism index and the country risk security factor is created mechanically, because the security factor of the Country Risk Index incorporates a measure of terrorism in addition to other measures of civil unrest, crime, and external security threats. We construct an alternative country risk index, termed corrected Country Risk Index (corrected CRI), based on the same factors as the original Country Risk Index but excluding security risk (see Appendix B). The cross-country regressions reported below use both the original and the corrected Country Risk Index. Regressions with the original Country Risk Index should underestimate the negative impact of terrorism on foreign direct investment, because terrorism risk is one of the components of that index. Regressions with the corrected Country Risk Index 
should overestimate the negative impact of terrorism on foreign direct investment, because the regression does not take into account the effect of other security risks which are likely to have a positive correlation with terrorist risk. Using both the original and the corrected Country Risk Index we obtain coefficients that can be interpreted respectively as a lower bound and an upper bound to the negative effect of terrorism on net FDI positions. As we show below, the regression results depend little on which one of the two the country risk indices, corrected or uncorrected, is used as a regressor.

Table 2 reports descriptive statistics for the economic variables. Net FDI positions may represent a large quantity relative to GDP and exhibit high disparities among countries; in our regression sample, net FDI positions over GDP average 28 percentage points with a standard deviation of 39 percentage points. Net FDI positions and national income are both negatively correlated with our measure of terrorist risk, whereas the level of FDI restrictions has a positive correlation with terrorism. Table 2 also reports descriptive statistics for demographic factors, governance measures and other explanatory variables used in the regressions reported later in the paper.

Table 3 reports cross-country regressions for the 110-country sample. Column (1) reports the result of regressing net FDI positions (over GDP) on a constant term and the Global Terrorism Index. The coefficient on the terrorism risk is negative and statistically different from zero at conventional test levels. The $R$-squared coefficient indicates that terrorism explains about 2 percent of the cross-country variance in net FDI positions.

The coefficient on the Global Terrorism Index in column (2) remains negative and significant after including log GDP per capita in the regression specification. As expected, log GDP per capita exhibits also a negative regression coefficient. The results remain similar when we include regional dummies in the regression specification in column (3).

In column (4) we include other potential determinants of foreign investment: a measure of the severity of the barriers to foreign capital and the WMRC Country Risk Index. As expected, the new variables exhibit negative coefficients. The inclusion of the overall country risk index and the other new variables leaves the coefficient on the Global Terrorism 
Index with a value of -0.21 percent of GDP and significant at the $10 \%$ level.

As explained above, because one component of the security factor of the Country Risk Index is a measure of terrorism, the coefficient on the Global Terrorism Index in column (4) incorporates a positive bias relative to a hypothetical regression using a measure of country risks which does not account for terrorism. Therefore, the coefficient on the Global Terrorism Index in column (4) can be interpreted as an upper bound on the coefficient of interest (that is, it underestimates the negative impact of terrorism on net FDI). To obtain a lower bound, in column (5) we estimate the same specification as in column (4) but using a corrected version of the Country Risk Index that does not include the security risk factor. Because security threats other than terrorism, which are unaccounted for in column (5), are likely to be positively correlated with terrorism and affect FDI negatively, the coefficient on the Global Terrorism Index incorporates a negative bias (it overestimates the negative impact of terrorism on net FDI). The value of the coefficient on terrorism risk in column (5) is -0.25 percent of GDP, slightly lower than the value of the same coefficient in column (4).

To give an idea of the magnitude of the estimated effect of terrorist risk, let us consider the effect of a one standard deviation change in terrorist risk on the net FDI position. A standard deviation change in terrorist risk is a change of 19.82 (18.77 in the 110-country regression sample) in the Global Terrorism Index. This change is about the difference in terrorist risk between Italy and the United States (the latter being more risky). Using the parameter estimated of Table 3 column (5), this increase in terrorist risk induces a fall in

the net FDI position of about 5 percent of GDP. This figure is large suggesting that the open-economy effect of terrorism may be substantial.

\subsection{Robustness Analysis}

In this section we perform several robustness checks on the specification of the regression equation. We extend the regression equation to include demographic factors, human capital, governance indicators, macroeconomic risk, financial factors, and other variables that 
could potentially affect the net FDI positions.

\subsubsection{Demographic Factors}

As a first robustness check we include in our regression demographic factors. The population age-structure may affect foreign direct investment. Life-cycle theory suggests that countries with young populations should be net debtors to the rest of the world. In addition, multinational corporations engaging in FDI often target countries where the population is young, so labor is an abundant production factor. Furthermore, the empirical evidence in Lane and Milesi-Ferretti (2002) indicates that demographic factors exert a significant effect on the net foreign assets position of countries, especially for the developing world.

In Table 4 we expand the set of explanatory variables by including demographic factors such as the fraction of population under age 14, the fraction of the population over age 65, and the age dependency ratio. ${ }^{9}$ The results of columns (1) to (3) indicate that our prior results are robust against the inclusion of measures of the percentages of the population under age 14 and over age 65. These age-range population variables exhibit statistically significant coefficients only when included together, as in columns (3) and (5). In column (4), we add the age dependency ratio to the regression as an additional explanatory variable. The coefficient on the age dependency ratio is not statistically significant, and the inclusion of this variable in the regression exerts little effect on the coefficients of the other variables.

Countries' levels of human capital plausibly influence international investment positions. In order to determine the importance of human capital in the determination of net FDI positions we have included in column (6) of Table 4 a proxy for human capital, the net enrollment rate in primary school. These data, from United Nations Educational Scientific and Cultural Organization (UNESCO), were available for 80 countries of the regression sample. We find that the coefficient on the enrollment rate is not statistically significant. The inclusion of this variable in the regression increases the standard errors of the other estimated coefficients and renders them insignificant (probably because of a combination

\footnotetext{
${ }^{9}$ The age dependency ratio is the fraction of the population under 14 and over 65 divided by the fraction between the ages of 14 and 65 .
} 
of the smaller sample size on the regression in column (6) and the high correlation between enrollment rate and other included variables). ${ }^{10}$

\subsubsection{Other Types of Country Risks}

While this paper focuses on terrorist risk, other types of country risk may be relatively important in international investment decisions. Here we test the robustness of our findings on terrorist risk by including the unique factors which comprise the WMRC Country Risk Index individually in our specification.

The WMRC Country Risk Index used in our regressions accounts for political, economic, legal, tax, operational, and security factors by aggregating them into a single measure of country risk. The political factor measures political instability and indicates how mature and well-established the political system is. The economic factor assesses the economic stance of the country in terms of the freedom of market forces and the macroeconomic fundamentals of the economy. The legal factor indicates how well-established the legal system is and whether necessary business laws are in place. The tax factor measures the coherence and fairness of the tax system as well as the overall level of taxes. The operational factor is an assessment of the degree of openness to FDI, the quality of infrastructure, how well the labor market functions, and bureaucracy and corruption. Finally, the security factor measures threats originating from civil unrest, crime, terrorism, as well as external threats.

Table 5 reports regressions where we have included political, economic, legal, tax, operational, and security factors. None of the first five factors significantly influence foreign direct investment positions either taken together (column (1)) or one at a time (columns (2)-(6)). The previous results for terrorist risk and the other explanatory variables remain robust across these regressions. In column (7), we introduce in the regression the security factor of the WMRC Country Risk Index (which includes terrorist risk) in lieu of the WMRC Global Terrorism Index. The coefficient on the security factor is negative and sta-

\footnotetext{
${ }^{10}$ Using the average number of years of schooling of adults and the net enrollment rate in secondary school as proxies for the level of human capital yields very similar results, but the sample is restricted to a smaller number of countries.
} 
tistically significant. This suggests that terrorism and, more generally, security are among the most apparent country-specific determinants of net FDI.

\subsubsection{Governance Indicators}

Here we test the robustness of our findings against potential omitted governance variables that may be important determinants of net FDI positions. To control for corruption and other forms of mis-governance, we employ a data set compiled by Kaufmann, Kraay and Mastruzzi (2004) that provides indicators on the efficacy of six dimensions of governance. These dimensions include:

1. Voice and accountability: measures an aggregate of civil liberties, political rights, and other aspects of the political system representing the accountability of the government;

2. Political stability and absence of violence: measures the likelihood that the government will not be destabilized or overthrown by violent means, including terrorism;

3. Government effectiveness: measures the ability of governments to implement and enforce their policies;

4. Regulatory quality: measures the absence of market-unfriendly policies;

5. Rule of law: measures the protection of property rights and the extent to which residents have confidence in the rules of society; and

6. Control of corruption: measures the degree to which public power is not perceived by the population as used for private gain. ${ }^{11}$

The political stability indicator, which incorporates (lack of) terrorism, exhibits a high correlation with the WMRC Global Terrorism Index in Table 2. We report the regression results including these six indicators of governance in columns (1)-(6) of Table 3. None of the coefficients of these indicators are statistically significant. More importantly, with the exception of column (2) the regression coefficient on the terrorism risk variable remains virtually unchanged through these regressions. The relative change of the coefficient on

\footnotetext{
${ }^{11}$ Scholarship on corruption and growth argues that corruption negatively affects growth by increasing risk and decreasing investment. Mauro (1995) finds a negative effect of corruption on investment.
} 
terrorism risk in column (2) reflects the mechanical relationship between the index of political stability and terrorism. In addition, the inclusion of the political stability index in the regression increases the standard error of the regression coefficient on the terrorism index variable, due to the high correlation between the political stability index and the GTI. The results in Table 6 indicate that, when we include the corrected Country Risk Index and the other previously tested variables in our regression, additional indicators of quality of governance do not have a significant effect on net FDI positions.

\subsubsection{Financial Factors, Macroeconomic Risk, and Natural Disasters}

International capital flows have been found to depend on the degree of financial development in a country (see, e.g., Albuquerque, Loayza and Servén, 2005). In a general sense, stock markets facilitate the flow of a significant share of foreign direct investment. Furthermore, newly established foreign firms, both those acquired through the stock market and those established as foreign direct investments, require financial services. Thus, as they make investment decisions foreign investors should account for the degree of development of a country's financial sector, and particularly the development of the banking sector, as both of these factors will affect the returns of their investments. The first column of Table 7 reports a regression where we include a common measure of financial development, the total volume of credit of the banking industry as a share of the GDP, as an additional explanatory variable. This measure of financial development does not exhibit a statistically significant coefficient and its inclusion renders most of the other regressors insignificant; the coefficient on the terrorism risk variable remains, however, marginally significant.

Exchange rate fluctuations affect international capital flows and stocks of foreign investment. Risk averse firms may decide not to invest in a country if exchange rate volatility is high (see, e.g., Campa, 1993). We have constructed a measure of foreign exchange fluctuations as the range of variation of the real effective exchange rate over the 1994-2003 period. Data availability for the construction of this variable restricts the sample to 55 countries only. The second column of Table 7 includes this measure of exchange rate fluctuations as an additional regressor. The evidence for this subsample indicates that this financial 
factor does not exhibit a significant coefficient and its inclusion renders the coefficient on the other regressors insignificant, potentially an effect of the small sample size.

It has been documented that a high degree of intervention of the government in the economy may deter foreign investment (see, e.g., Albuquerque, Loayza and Servén, 2005). Using the ratio of government consumption over GDP as a measure of government intervention, we obtain the results reported in column (3) of Table 7 . The coefficient on the additional regressor is not statistically significant. The inclusion of the measure of government intervention does not affect greatly the coefficients on the terrorism risk index and other variables, or their statistical significance.

Growth instability potentially affects FDI as a source of uncertainty (see, e.g., Albuquerque, Loayza and Servén, 2005). While a fast-growing economy might attract foreign investment, macroeconomic instability might deter foreign investment. To account for growth variability we use the standard deviation of GDP growth over the decade 1994-2003. Column (4) of Table 7 indicates that growth variability is not a significant determinant of the net foreign investment position. However, the coefficients on terrorist risk and the other explanatory variables remain significant.

The theoretical model developed in this article conceptualizes terrorism as catastrophic risk. However, terrorism is not the only instance of catastrophic risk. To further validate our empirical findings, we include in column (5) of Table 7 a measure of earthquake risk (the number of deaths caused by earthquakes during the period 1994-2003 normalized by 100,000 population in 2003). ${ }^{12}$ If our empirical approach to investigate the effects of catastrophic risk on investment is appropriate, this new variable should exhibit a negative coefficient in our regression. Indeed, the coefficient on the earthquake risk variable is negative and significant at the $10 \%$ level. The inclusion of this variable in the regression leaves the coefficient of terrorist risk virtually unchanged.

\footnotetext{
${ }^{12}$ Natural disaster data are from the OFDA/CRED International Disasters Data Base.
} 


\subsection{Discussion}

Our results demonstrate that terrorism risk has significant explanatory power on net FDI investment positions. In principle, the impact of terrorism on FDI positions estimated in our regressions would be exacerbated if omitted determinants of FDI are negatively correlated with terrorism. We show, however, that our regression results are robust under alternative specifications, which control for a variety of factors suspected to affect foreign investment.

On the contrary, there are a number of reasons to believe that our estimates may be, in fact, conservative.

First, our estimates of the impact of terrorism on foreign investment will be biased by reverse causation if the presence of foreign capital in a country induces a terrorist response. Notice however that, in this case, reverse causation would create a positive bias in the estimated coefficient on terrorism risk. Because we estimate a negative coefficient on the terrorism risk variable, the potential bias created by reverse causation would not change the qualitative conclusions of this study, i.e. the true coefficient would also be negative but larger in absolute value.

Moreover, notice that most of the estimates in this section reflect the degree of statistical association between terrorism and net FDI positions over GDP holding constant the level of per-capita GDP of a country (and other explanatory variables). Therefore, our analysis will underestimate the long-run effects of a terrorist shock on an economy if foreign ownership of the capital of a country boosts the level of per-capita income of the country (e.g., via transfers of technology), and if increases in per-capita income tend to reduce the level of terrorism. Under these conditions the negative impact of a terrorism shock would be exacerbated by feedback effects. ${ }^{13}$

There are two additional reasons to believe that our estimates provide in fact a conservative measure of the impact of terrorism on foreign direct investment. First, the country

\footnotetext{
${ }^{13}$ However, empirical studies have failed to find evidence of the existence of a causal effect of per-capita income on terrorism. See Krueger and Laitin (2003) and Abadie (2004).
} 
latent level of terrorist risk cannot be directly observed and the GTI will measure it with error. If terrorism measurement error is "classical" (additive and independent of the latent terrorist risk) our estimates will be biased towards zero. Second, our estimates of the effects of terrorism on capital flows are attenuated to the extend that they reflect only the impact on capital flows across countries. If terrorist risk levels vary within countries, the effect of terrorism on the regions that are most affected by it will be more severe than what our estimates suggest.

\section{Conclusions}

In this paper we have shown how terrorism influences the equilibrium decisions of international investors in an integrated world economy. We have introduced terrorism as catastrophic risk in a standard endogenous growth model and analyzed the effect of an increase in terrorist risk on the net FDI position of countries. The model suggests that in an integrated world economy, where international investors are able to diversify other country risks, terrorism may induce large movements of capital across countries. The em-

pirical evidence, based on cross-country regressions, indicates that terrorist risk depresses net foreign investment positions. This relationship is robust to the introduction of demographic factors, country-specific risk indexes, governance indicators, and other financial and macroeconomic factors such as per capita GDP and FDI restrictions which might determine the country's FDI position.

Our estimates suggest that a one standard deviation increase in the intensity of terrorism produces a 5 percent fall in the net FDI position of the country (normalized by GDP). Both the model and the empirical evidence suggest that the open economy channel may be an important avenue through which terrorism hurts the economy. 


\section{Appendix A: Solution to the Model}

For the model in Section II, the value function is:

$$
V(k, t)=\max E\left[\int_{t}^{\infty} \mathrm{e}^{-\beta s} \frac{C(s)^{1-\gamma}-1}{1-\gamma} d s \mid K(t)=k\right],
$$

where the maximum is taken over all feasible consumption plans. We impose the transversality condition

$$
\lim _{t \rightarrow \infty} E[V(K(t), t)]=0 .
$$

Notice that $V(k)=\mathrm{e}^{\beta t} V(k, t)$ does not depend on $t$. Using this property of the value function the Hamilton-Jacobi-Bellman equation simplifies to:

$$
\begin{aligned}
\beta V(k)=\max _{c, v}\left\{\frac{c^{1-\gamma}-1}{1-\gamma}\right. & +\frac{\partial V(k)}{\partial k}\left(\alpha v k+\alpha^{*}(1-v) k-c\right)+\frac{1}{2} \frac{\partial^{2} V(k)}{\partial k^{2}}\left(\sigma_{W}^{2} v^{2} k^{2}+\sigma_{W}^{* 2}(1-v)^{2} k^{2}\right) \\
& \left.+\lambda(V(k-\delta v k)-V(k))+\lambda^{*}\left(V\left(k-\delta^{*}(1-v) k\right)-V(k)\right)\right\} .
\end{aligned}
$$

Solving the maximization problem on the left-hand side of last equation, we obtain the following first-order conditions (FOC):

$$
\begin{gathered}
\widehat{c}^{-\gamma}-\frac{\partial V(k)}{\partial k}=0, \\
\frac{\partial V(k)}{\partial k}\left(\alpha-\alpha^{*}\right) k+\frac{\partial^{2} V(k)}{\partial k^{2}}\left(\sigma_{W}^{2} \widehat{v} k^{2}-\sigma_{W}^{* 2}(1-\widehat{v}) k^{2}\right) \\
-\lambda \frac{\partial V(k-\delta \widehat{v} k)}{\partial k} \delta k+\lambda^{*} \frac{\partial V\left(k-\delta^{*}(1-\widehat{v}) k\right)}{\partial k} \delta^{*} k=0 .
\end{gathered}
$$

The second-order conditions (SOC) are:

$$
\begin{gathered}
-\gamma \widehat{c}^{-\gamma-1}<0, \\
\frac{\partial^{2} V(k)}{\partial k^{2}}\left(\sigma_{W}^{2} k^{2}+\sigma_{W}^{* 2} k^{2}\right)+\lambda \frac{\partial^{2} V(k(1-\delta \widehat{v}))}{\partial k^{2}} \delta^{2} k^{2}+\lambda^{*} \frac{\partial^{2} V\left(k\left(1-\delta^{*}(1-\widehat{v})\right)\right)}{\partial k^{2}} \delta^{* 2} k^{2}<0 .
\end{gathered}
$$

Try the solution:

$$
V(k)=\frac{\mu k^{1-\gamma}-1 / \beta}{1-\gamma} .
$$


For the FOC, we obtain:

$$
\begin{gathered}
\widehat{c}=\mu^{-1 / \gamma} k, \\
\left(\alpha-\alpha^{*}\right)-\gamma\left(\sigma_{W}^{2} \widehat{v}-\sigma_{W}^{* 2}(1-\widehat{v})\right)-\lambda \delta(1-\delta \widehat{v})^{-\gamma}+\lambda^{*} \delta^{*}\left(1-\delta^{*}(1-\widehat{v})\right)^{-\gamma}=0 .
\end{gathered}
$$

It is easy to see that the SOC hold if $\widehat{c} \geq 0$ and $0 \leq \widehat{v} \leq 1$. In particular, the derivative of the left hand side of last equation with respect to $\widehat{v}$ is negative for $0 \leq \widehat{v} \leq 1$. Therefore, evaluating the left hand side of last equation at $\widehat{v}=0$ and $\widehat{v}=1$ implies the following conditions for an interior solution:

$$
\begin{gathered}
\left(\alpha-\alpha^{*}\right)+\gamma \sigma_{W}^{* 2}-\lambda \delta+\lambda^{*} \delta^{*}\left(1-\delta^{*}\right)^{-\gamma}>0 \\
\left(\alpha-\alpha^{*}\right)-\gamma \sigma_{W}^{2}-\lambda \delta(1-\delta)^{-\gamma}+\lambda^{*} \delta^{*}<0
\end{gathered}
$$

From the HJB equation, we obtain a value for $\mu^{-1 / \gamma}$ which yields $C(t)=\pi_{C} K(t)$, where

$$
\begin{aligned}
\pi_{C}=\frac{1}{\gamma}\left(\beta+(\gamma-1)\left(\alpha \widehat{v}+\alpha^{*}(1-\widehat{v})\right)\right. & -\frac{1}{2} \gamma(\gamma-1)\left(\sigma_{W}^{2} \widehat{v}^{2}+\sigma_{W}^{* 2}(1-\widehat{v})^{2}\right) \\
& \left.-\lambda\left[(1-\delta \widehat{v})^{1-\gamma}-1\right]-\lambda^{*}\left[\left(1-\delta^{*}(1-\widehat{v})\right)^{1-\gamma}-1\right]\right) .
\end{aligned}
$$

As shown in section II:

$$
\frac{d \pi_{C}}{d \lambda}=\frac{1}{\gamma}\left[1-(1-\delta \widehat{v})^{1-\gamma}\right] \begin{aligned}
& >0 \text { if } \gamma<1 \\
& \leq 0 \text { if } \gamma \geq 1
\end{aligned} .
$$

Terrorism exerts a substitution and an income effect on consumption. To obtain the substitution effect, differentiate $C$ with respect to $\lambda$ for a fixed level of lifetime utility $v_{0}$ (compensated by changes in $K(0)$ ). We know that $V(K(0), 0)=V(K(0))=$ $\left(\mu K(0)^{1-\gamma}-1 / \beta\right) /(1-\gamma)$. Differentiating this expression for $V(0)=v_{0}$, we obtain:

$$
\left(\frac{\partial K(0)}{\partial \lambda}\right)_{V(0)=v_{0}}=-\frac{1}{1-\gamma} \frac{\partial \mu / \partial \lambda}{\mu} K(0)=\frac{\gamma}{1-\gamma} \frac{\partial \pi_{C} / \partial \lambda}{\pi_{C}} K(0) \geq 0,
$$

since $\mu^{-1 / \gamma}=\pi_{C}$. Evaluate the substitution effect at $K(0)$,

$$
\left(\frac{d C}{d \lambda}\right)_{V(0)=v_{0}}=\frac{d \pi_{C}}{d \lambda} K(0)+\pi_{C}\left(\frac{\partial K(0)}{\partial \lambda}\right)_{V(0)=v_{0}}=\frac{1}{1-\gamma} \frac{d \pi_{C}}{d \lambda} K(0) \geq 0 .
$$

The income effect is:

$$
\frac{d C}{d \lambda}-\left(\frac{d C}{d \lambda}\right)_{V(0)=v_{0}}=-\frac{\gamma}{1-\gamma} \frac{d \pi_{C}}{d \lambda} K(0) \leq 0
$$


Given the form of the value function, the transversality condition for this problem becomes:

$$
\lim _{t \rightarrow \infty} E\left[\mathrm{e}^{-\beta t} K(t)^{1-\gamma}\right]=0 .
$$

To verify this condition we first apply Ito's Lemma for jump-diffusions to obtain:

$$
\begin{aligned}
d \ln K(t) & =\left(\alpha \widehat{v}+\alpha^{*}(1-\widehat{v})-\pi_{C}-\frac{1}{2}\left(\sigma_{W}^{2} \widehat{v}^{2}+\sigma_{W}^{* 2}(1-\widehat{v})^{2}\right)\right) d t \\
& +\sigma_{W} \widehat{v} d W(t)+\sigma_{W}^{*}(1-\widehat{v}) d W^{*}(t) \\
& +\ln (1-\delta \widehat{v}) d P(t)+\ln \left(1-\delta^{*}(1-\widehat{v})\right) d P^{*}(t)
\end{aligned}
$$

Therefore, $\ln K(t)$ is also a jump-diffusion. Notice that

$$
E\left[\mathrm{e}^{-\beta t} K(t)^{1-\gamma}\right]=E\left[\mathrm{e}^{-\beta t} \mathrm{e}^{(1-\gamma) \ln K(t)}\right] .
$$

Because $\ln K(t)$ is also a jump-diffusion, we can apply the results in Duffie, Pan, and Singleton (2000), to obtain (under regularity conditions):

$$
E\left[\mathrm{e}^{-\beta(t-s)} K(t)^{1-\gamma}\right]=\mathrm{e}^{a(s)+b(s) \ln K(s)},
$$

with

$$
\begin{aligned}
\frac{\partial a(s)}{\partial s}= & \beta+(\gamma-1)\left(\alpha \widehat{v}+\alpha^{*}(1-\widehat{v})-\pi_{C}\right)-\frac{1}{2} \gamma(\gamma-1)\left(\sigma_{W}^{2} \widehat{v}^{2}+\sigma_{W}^{* 2}(1-\widehat{v})^{2}\right) \\
- & \lambda\left[(1-\delta \widehat{v})^{1-\gamma}-1\right]-\lambda^{*}\left[\left(1-\delta^{*}(1-\widehat{v})\right)^{1-\gamma}-1\right] \\
& =\gamma \pi_{C}-(\gamma-1) \pi_{C}=\pi_{C} \\
& \frac{\partial b(s)}{\partial s}=0
\end{aligned}
$$

$a(t)=0$, and $b(t)=1-\gamma$. As a result, making $s=0$, we obtain:

$$
E\left[\mathrm{e}^{-\beta t} K(t)^{1-\gamma}\right]=K_{0}^{1-\gamma} \mathrm{e}^{-\pi_{C} t} .
$$

Therefore, the transversality condition holds if and only if $\pi_{C}>0$. 


\section{Appendix B: Additional Data Information}

- Foreign Direct Investment assets and liabilities, 196 countries and territories, 2003. The United Nations Conference on Trade and Development.

- Global Terrorism Index, 186 countries and territories, 2003/4. World Markets Research Centre.

- Country Risk Index, 186 countries and territories, 2003. World Markets Research Centre's analysts rate the political, economic, legal, tax, operational, and security environments of each country and combine those six factors into a single index given by:

$\sqrt{\left[\begin{array}{c}\left(0.25 \times(\text { Political Risk })^{2}\right)+\left(0.25 \times(\text { Economic Risk })^{2}\right)+\left(0.15 \times(\text { Legal Risk })^{2}\right) \\ \left(0.15 \times(\text { Tax Risk })^{2}\right)+\left(0.10 \times(\text { Operational Risk })^{2}\right)+\left(0.10 \times(\text { Security Risk })^{2}\right)\end{array}\right]}$.

- Corrected Country Risk Index (net of security risk):

$$
\sqrt{\frac{1}{0.9}\left[\begin{array}{c}
\left(0.25 \times(\text { Political Risk })^{2}\right)+\left(0.25 \times(\text { Economic Risk })^{2}\right)+\left(0.15 \times(\text { Legal Risk })^{2}\right) \\
\left(0.15 \times(\text { Tax Risk })^{2}\right)+\left(0.10 \times(\text { Operational Risk })^{2}\right)
\end{array}\right.} .
$$

- Gross Domestic Product in US dollars for 2003. The World Bank, World Development Indicators.

- Population. The World Bank. World Development Indicators.

- Percentage of population aged 0-14 and 65 and over, 2002. The World Bank, World Development Indicators.

- The Age Dependency Ratio is computed as population aged 0-14 or 65 and over divided by population aged 15-64.

- Index of capital flows and foreign investment restrictions, a factor of the Index of Economic Freedom. The Heritage Foundation and The Wall Street Journal. Miles et al, 2004, http://www.heritage.org/research/features/index/. 
- Restrictions on repatriations of FDI earnings. International Monetary Fund, 2001b.

- The net enrollment rate in primary school and the net enrollment rate in secondary school. These data, from United Nations Educational Scientific and Cultural Organization (UNESCO).

- Average Years of Schooling of Adults. The World Bank Education Statistics.

- Governance Indicators. Kaufmann, Kraay and Mastruzzi (2004).

- Corruption Perception Index. Internet Center for Corruption Research (University of Passau and Transparency International, http://www.icgg.org.

- Private credit by deposit money banks and other financial institutions to GDP. Financial Structure and Economic Development Database, See Beck, Demirguc-Kunt and Levine (1999). This database has been updated to 2001. http://www . worldbank. org/research/projects/finstructure/database.htm

- Real effective exchange rate. International Monetary Fund. International Financial Statistics, series code (XXX..RECZF...). 1994-2003.

- General government final consumption expenditure (\% of GDP). 1994-2003 average. International Monetary Fund, International Financial Statistics.

- Standard Deviation of growth rate. Computed as the standard deviation of the annual growth rates of GDP (constant prices, local currency units) for the period 1994-2003. International Monetary Fund. International Financial Statistics.

- Earthquake risk index. Computed as the number of deaths caused by earthquakes during the years 1994-2003 (OFDA/CRED International Disasters Database, (http://www.em-dat.net/) per 100,000 population in the year 2003. 


\section{REFERENCES}

Abadie, Alberto (2004), "Poverty, Political Freedom, and the Roots of Terrorism," NBER Working Paper no. 10859.

Abadie, Alberto and Javier Gardeazabal (2003), "The Economic Cost of Conflict: A Case Study of the Basque Country," American Economic Review 93, 113-132.

Albuquerque, Rui, Norman Loayza and Luis Servén (2005), "World Market Integration through the Lens of Foreign Direct Investors," Journal of International Economics 66(2), 267-295.

Beck, Thorsten, Asli Demirguc-Kunt and Ross Levine (1999), "A New Database on Financial Development and Structure," The World Bank. Policy Research Working Paper no. WPS 2146.

Becker, Gary and Kevin Murphy (2001), "Prosperity Will Rise Out of the Ashes," Wall Street Journal Oct 29, 2001.

Becker, Gary and Yona Rubinstein (2004), "Fear and the Response to Terrorism: An Economic Analysis," mimeo.

Campa, José Manuel (1993), "Entry by Foreign Firms in the United States under Exchange Rate Uncertainty," Review of Economics and Statistics 75(4), 614-22.

Duffie, Darrell, Jun Pan, and Kenneth Singleton (2000), "Transform Analysis and Asset Pricing for Affine Jump-Diffusions," Econometrica 68(6), 1343-1376.

Enders, Walter and Todd Sandler (1996), "Terrorism and Foreign Direct Investment in Spain and Greece," Kyklos 49(3), 331-352.

Enders, Walter, Todd Sandler and Gerald F. Parise (1992), "An Econometric Analysis of the Impact of Terrorism on Tourism," Kyklos 45, 531-554.

Frey, Bruno S., Simon Luechinger and Alois Stutzer (2004a), "Valuing Public Goods: The Life Satisfaction Approach," Institute for Empirical Research in Economics, University of Zurich. Working Paper 184.

Frey, Bruno S., Simon Luechinger and Alois Stutzer (2004b), "Calculating Tragedy: Assessing the Costs of Terrorism," Institute for Empirical Research in Economics ,University of Zurich. Working Paper 205.

Global Business Policy Council (2004), "FDI Confidence Index," A.T. Kearney, Alexandria, Virginia.

Griliches, Zvi and Jerry A. Hausman (1986), "Errors in Variables in Panel Data," Journal of Econometrics 31, 93-118. 
IMF (2001a), "How Has September 11 Influenced the Global Economy?" World Economic Outlook.

IMF (2001b), "Annual Report on Exchange Agreements and Exchange Restrictions," International Monetary Fund.

Kaufmann, Daniel, Aart Kraay and Massimo Mastruzzi (2004), "Governance Matters III: Governance Indicators for 1996-2002," World Bank Economic Review 18, 253-287.

Kraay, Aart and Jaume Ventura (2000), "Current Accounts in Debtor and Creditor Countries," Quarterly Journal of Economics 115(4), 1137-1166.

Kraay, Aart and Jaume Ventura (2002), "Current Accounts in the Long and Short Run," NBER Macroeconomics Annual.

Krueger, Alan B. and David D. Laitin (2003), "Kto Kogo?: A Cross-Country Study of the Origins and Targets of Terrorism," mimeo.

Lane, Philip R. and Gian Maria Milesi-Ferretti (2002), "Long-Term Capital Movements," in Ben S. Bernanke and Kenneth Rogoff editors, NBER Macroeconomics Annual 2002, Volume 16. Cambridge and London: MIT Press.

Li, Dajin (2002), "Is the $A K$ model still alive? The long-run relation between growth and investment re-examined," Canadian Journal of Economics 35, 92-114.

McGrattan, Ellen R. (1998), "A Defense of AK Models," Federal Reserve Bank of Minneapolis Quarterly Review 22(4), 13-27.

Mauro, Paolo (1995), "Corruption and Growth," Quarterly Journal of Economics 110(3), 681-712.

Miles, Marc A., Edwin J. Feulner, Jr., Mary Anastasia O'Grady, and Ana I. Eiras (2004), Index of Economic Freedom. The Heritage Foundation/Wall Street Journal.

Obtsfeld, Maurice (1994), "Risk Taking, Global Diversification, and Growth," American Economic Review 84(5), 1310-1329.

OECD (2001), Organisation for Economic Co-operation and Development. Economic Outlook, 71 .

Pshisva, Rony and Gustavo A. Suarez (2004), "Crime and Finance: Evidence from Colombia," Harvard University, Department of Economics.

Turnovsky, Stephen (1997), "International Macroeconomic Dynamics," MIT Press, Cambridge Massachusetts. 
UNCTAD (2002), United Nations Conference on Trade and Development. "FDI Downturn in 2001 Touches Almost All Regions" Press release TAD/INF/PR/36, 21 January 2002.

UNCTAD (2004), United Nations Conference on Trade and Development. Foreign Investment Database. http://www.unctad.org.

United States Congress, Joint Economic Committee (2002), "The Economic Costs of Terrorism".

World Market Research Center (2003), "Global Terrorism Index 2003/4." 

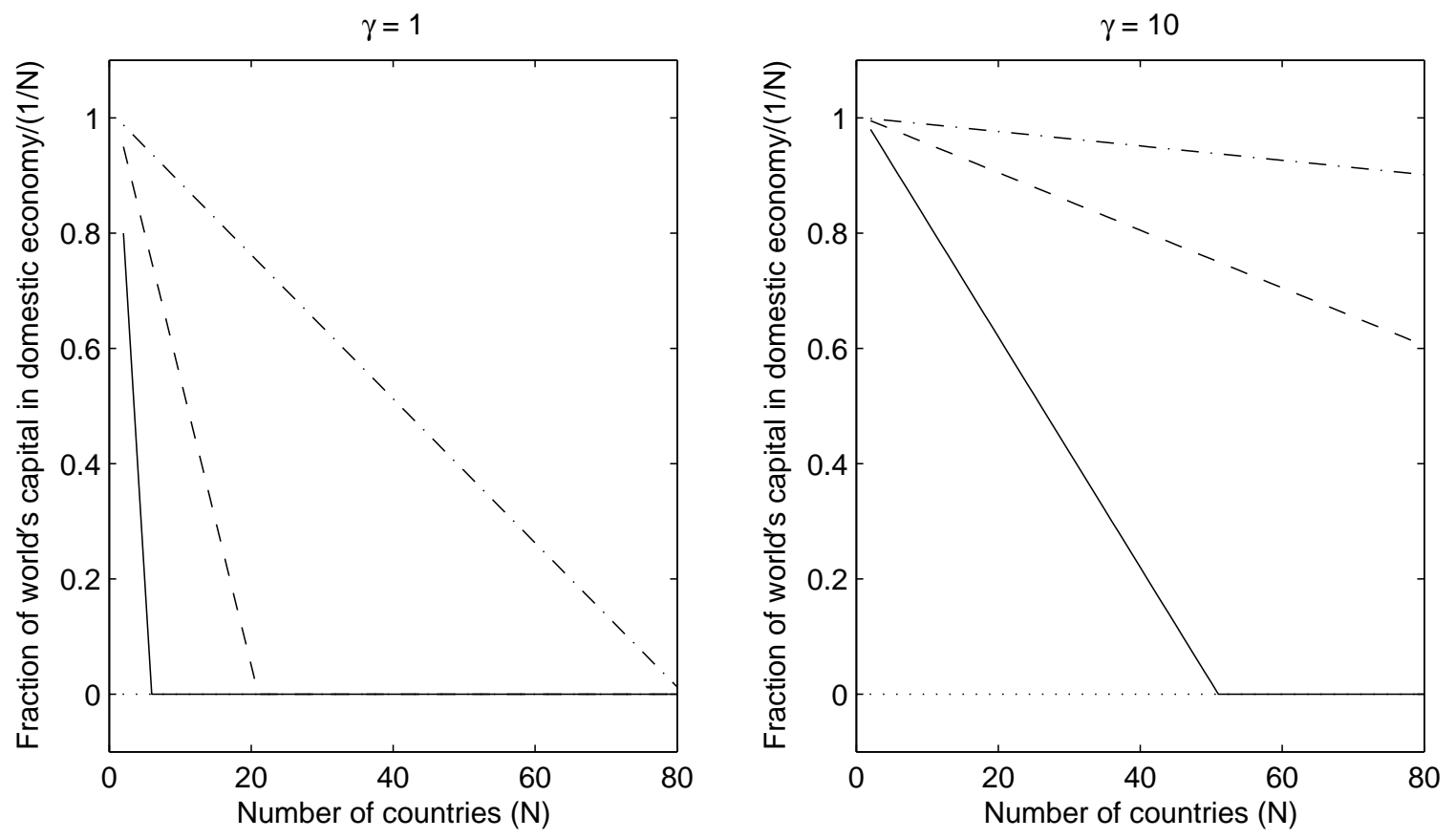

$$
\begin{array}{r}
\sigma /\left(\lambda^{1 / 2} \delta\right)=100 \\
---\sigma /\left(\lambda^{1 / 2} \delta\right)=200 \\
-\cdot-\sigma /\left(\lambda^{1 / 2} \delta\right)=400
\end{array}
$$

Figure 1. Diversification and the Effect of Terrorism on Investment 


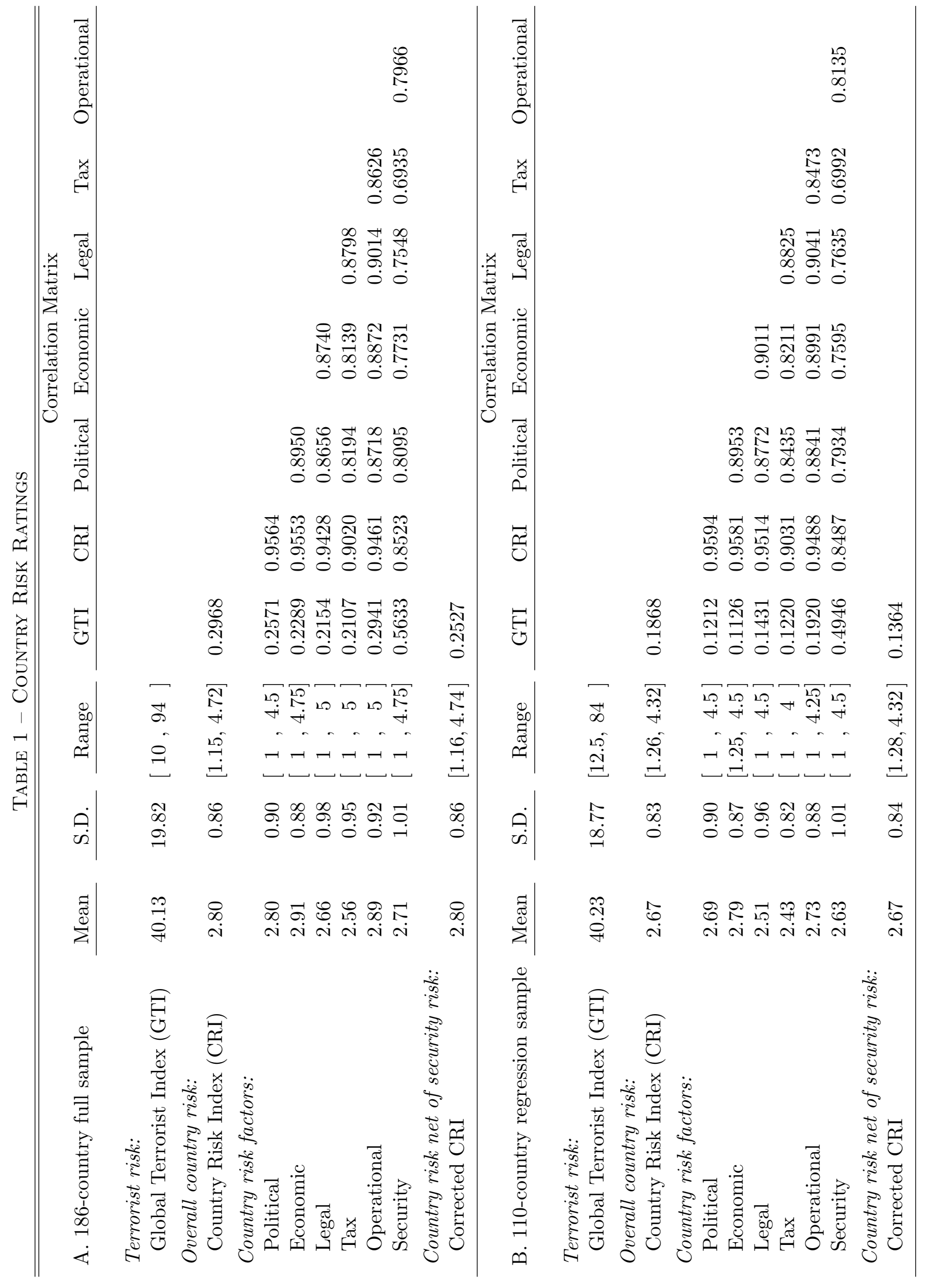


TAble 2 - Descriptive Statistics for Economic VARiables

\begin{tabular}{|c|c|c|c|c|c|}
\hline & $\begin{array}{l}\text { Number of } \\
\text { Countries }\end{array}$ & Mean & S.D. & Range & $\begin{array}{c}\text { Correlation } \\
\text { with GTI }\end{array}$ \\
\hline Net FDI Position (over GDP) & 110 & 0.28 & 0.39 & {$[-0.62,2.97$} & -0.1360 \\
\hline Log per capita GDP & 110 & 7.91 & 1.61 & {$[4.88,10.79]$} & -0.0639 \\
\hline FDI Restrictions & 98 & 2.66 & 0.91 & 1,5 & 0.0714 \\
\hline \multicolumn{6}{|l|}{ Demographic factors: } \\
\hline Population under 14 (percentage) & 110 & 29.19 & 10.38 & {$[14.08,48.88]$} & 0.1020 \\
\hline Population over 65 (percentage) & 110 & 8.05 & 5.33 & {$[2.21,18.85]$} & -0.1144 \\
\hline Age dependency ratio & 110 & 0.61 & 0.17 & {$[0.16,1.04$} & 0.0610 \\
\hline Net primary enrollment rate & 84 & 89.92 & 12.26 & {$[33.96,104.54]$} & 0.1285 \\
\hline \multicolumn{6}{|l|}{ Governance factors: } \\
\hline Voice and accountability & 110 & 0.16 & 0.94 & {$[-2.05,1.72$} & -0.1885 \\
\hline Political stability & 110 & 0.14 & 0.95 & {$[-2.28,1.63$} & -0.4750 \\
\hline Government effectiveness & 110 & 0.13 & 1.03 & {$[-1.56,2.26$} & -0.1051 \\
\hline Regulatory quality & 110 & 0.21 & 0.95 & {$[-1.95,1.93$} & -0.1259 \\
\hline Rule of law & 110 & 0.13 & 1.01 & {$[-1.76,2.03$} & -0.1808 \\
\hline Control of corruption & 110 & 0.11 & 1.06 & {$[-1.70,2.39$} & -0.1480 \\
\hline \multicolumn{6}{|l|}{ Macroeconomic factors: } \\
\hline Credit (over GDP) & 73 & 0.58 & 0.45 & {$[0.04,1.61$} & 0.1902 \\
\hline Real effective $\mathrm{X}$-rate range & 58 & 26.60 & 15.78 & {$[6.97,58.22]$} & -0.0029 \\
\hline Gov. Consumption (over GDP) & 108 & 16.46 & 6.59 & {$[5.40,42.43]$} & -0.2367 \\
\hline Std. Dev. growth rate & 104 & 0.04 & 0.04 & {$[0.00,0.38$} & 0.0254 \\
\hline \multicolumn{6}{|l|}{ Other factors: } \\
\hline Earthquake risk index & 109 & 0.28 & 1.76 & $0 \quad, 17.74]$ & 0.0550 \\
\hline
\end{tabular}


Table 3 - Baseline Specifications

Dependent variable Net FDI positions over GDP

\begin{tabular}{lccccc}
\hline \hline & & & & & \\
& $(1)$ & $(2)$ & $(3)$ & $(4)$ & $(5)$ \\
\hline \multirow{2}{*}{ Constant } & & & & & \\
& $\left(0.3944^{* *}\right.$ & $1.0465^{* *}$ & 0.6996 & $1.5791^{* *}$ & $1.5354^{* *}$ \\
Terrorist risk & $-0.0028^{* *}$ & $-0.0033^{* *}$ & $-0.0028^{*}$ & $-0.0021^{*}$ & $-0.0025^{* *}$ \\
& $(0.0014)$ & $(0.0013)$ & $(0.0015)$ & $(0.0012)$ & $(0.0012)$ \\
Log GDP per capita & & $-0.0802^{* *}$ & -0.0549 & $-0.1125^{* *}$ & $-0.1088^{* *}$ \\
& & $(0.0321)$ & $(0.0395)$ & $(0.0315)$ & $(0.0332)$ \\
FDI restrictions & & & & $-0.0611^{*}$ & $-0.0622^{*}$ \\
& & & & $(0.0326)$ & $(0.0339)$ \\
Country Risk & & & & $-0.1183^{* *}$ & \\
& & & & $(0.0571)$ & \\
Corrected Country Risk & & & & & $-0.1047^{*}$ \\
& & & & & $(0.0599)$ \\
Regional Dummies & no & no & yes & yes & yes \\
\hline Number of countries & 110 & 110 & 110 & 98 & 98 \\
$R$-squared & 0.02 & 0.02 & 0.16 & 0.31 & 0.30 \\
\hline \hline Robust standard
\end{tabular}

Robust standard errors in parentheses.

** indicates statistical significance at the $5 \%$ level.

* indicates statistical significance at the $10 \%$ level.

Regional dummies: Middle East and North Africa, Latin America and the Caribbean, Eastern Europe and Central Asia, Rest of Asia, Sub-Saharan Africa and Western Europe. 
TABle 4 - Demographic FaCtors

Dependent variable Net FDI positions over GDP

\begin{tabular}{|c|c|c|c|c|c|c|}
\hline & (1) & $(2)$ & $(3)$ & (4) & $(5)$ & $(6)$ \\
\hline Constant & $\begin{array}{l}1.5343^{* *} \\
(0.4312)\end{array}$ & $\begin{array}{l}1.6677^{* *} \\
(0.6446)\end{array}$ & $\begin{array}{l}2.3874^{* *} \\
(0.7155)\end{array}$ & $\begin{array}{l}2.0173^{* *} \\
(0.6040)\end{array}$ & $\begin{array}{l}2.4245^{* *} \\
(0.6971)\end{array}$ & $\begin{array}{c}1.7870^{* *} \\
(0.7360)\end{array}$ \\
\hline Terrorist risk & $\begin{array}{r}-0.0027^{* *} \\
(0.0012)\end{array}$ & $\begin{array}{c}-0.0024^{* *} \\
(0.0012)\end{array}$ & $\begin{array}{c}-0.0024^{* *} \\
(0.0012)\end{array}$ & $\begin{array}{c}-0.0023^{*} \\
(0.0012)\end{array}$ & $\begin{array}{c}-0.0021^{*} \\
(0.0012)\end{array}$ & $\begin{array}{r}-0.0019 \\
(0.0013)\end{array}$ \\
\hline Log GDP per capita & $\begin{array}{c}-0.0910^{* *} \\
(0.0415)\end{array}$ & $\begin{array}{c}-0.1177^{* *} \\
(0.0476)\end{array}$ & $\begin{array}{c}-0.1192^{* *} \\
(0.0459)\end{array}$ & $\begin{array}{c}-0.1358^{* *} \\
(0.0422)\end{array}$ & $\begin{array}{c}-0.1226^{* *} \\
(0.0440)\end{array}$ & $\begin{array}{r}-0.0819 \\
(0.0514)\end{array}$ \\
\hline FDI restrictions & $\begin{array}{c}-0.0637^{*} \\
(0.0342)\end{array}$ & $\begin{array}{c}-0.0620^{*} \\
(0.0345)\end{array}$ & $\begin{array}{c}-0.0649^{*} \\
(0.0351)\end{array}$ & $\begin{array}{c}-0.0631^{*} \\
(0.0346)\end{array}$ & $\begin{array}{c}-0.0639^{*} \\
(0.0340)\end{array}$ & $\begin{array}{r}-0.0551 \\
(0.0404)\end{array}$ \\
\hline Country Risk & & & & & $\begin{array}{c}-0.1129^{*} \\
(0.0575)\end{array}$ & \\
\hline Corrected Country Risk & $\begin{array}{c}-0.1066^{*} \\
(0.0606)\end{array}$ & $\begin{array}{c}-0.1032^{*} \\
(0.0585)\end{array}$ & $\begin{array}{c}-0.1000^{*} \\
(0.0595)\end{array}$ & $\begin{array}{c}-0.0995^{*} \\
(0.0590)\end{array}$ & & $\begin{array}{r}-0.0222 \\
(0.0768)\end{array}$ \\
\hline Population under 14 & & $\begin{array}{c}-0.0025 \\
(0.0066)\end{array}$ & $\begin{array}{c}-0.0159^{*} \\
(0.0090)\end{array}$ & & $\begin{array}{c}-0.0158^{*} \\
(0.0090)\end{array}$ & $\begin{array}{r}-0.0100 \\
(0.0095)\end{array}$ \\
\hline Population over 65 & $\begin{array}{l}-0.0128 \\
(0.0134)\end{array}$ & & $\begin{array}{c}-0.0336^{*} \\
(0.0187)\end{array}$ & & $\begin{array}{c}-0.0335^{*} \\
(0.0187)\end{array}$ & $\begin{array}{r}-0.0263 \\
(0.0214)\end{array}$ \\
\hline Age dependency ratio & & & & $\begin{array}{c}-0.4554 \\
(0.3002)\end{array}$ & & \\
\hline Net primary enrollment & & & & & & $\begin{array}{r}-0.0014 \\
(0.0034)\end{array}$ \\
\hline Number of countries & 98 & 98 & 98 & 98 & 98 & 80 \\
\hline$R$-squared & 0.31 & 0.31 & 0.34 & 0.32 & 0.34 & 0.32 \\
\hline
\end{tabular}

Robust standard errors in parentheses.

** indicates statistical significance at the $5 \%$ level.

* indicates statistical significance at the $10 \%$ level.

All regressions include regional dummies. 
Table 5: Country Specific Risks

Dependent variable Net FDI positions over GDP

\begin{tabular}{|c|c|c|c|c|c|c|c|}
\hline & $(1)$ & $(2)$ & $(3)$ & $(4)$ & $(5)$ & (6) & $(7)$ \\
\hline Constant & $\begin{array}{l}2.4596^{* *} \\
(0.8291)\end{array}$ & $\begin{array}{l}2.1268^{* *} \\
(0.6562)\end{array}$ & $\begin{array}{l}2.3859^{* *} \\
(0.7351)\end{array}$ & $\begin{array}{l}2.1799^{* *} \\
(0.6752)\end{array}$ & $\begin{array}{l}2.0688^{* *} \\
(0.63701)\end{array}$ & $\begin{array}{c}2.3450^{* *} \\
(0.7528)\end{array}$ & $\begin{array}{l}2.1225^{* *} \\
(0.6094)\end{array}$ \\
\hline Terrorist risk & $\begin{array}{c}-0.0024^{*} \\
(0.0014)\end{array}$ & $\begin{array}{c}-0.0025^{* *} \\
(0.0012)\end{array}$ & $\begin{array}{c}-0.0025^{* *} \\
(0.0012)\end{array}$ & $\begin{array}{c}-0.0026^{* *} \\
(0.0012)\end{array}$ & $\begin{array}{c}-0.0027^{* *} \\
(0.0012)\end{array}$ & $\begin{array}{l}-0.0023^{*} \\
(0.0012)\end{array}$ & \\
\hline Log GDP per capita & $\begin{array}{c}-0.1252^{* *} \\
(0.0529)\end{array}$ & $\begin{array}{c}-0.0960^{* *} \\
(0.0404)\end{array}$ & $\begin{array}{c}-0.1192^{* *} \\
(0.0464)\end{array}$ & $\begin{array}{c}-0.1022^{* *} \\
(0.0407)\end{array}$ & $\begin{array}{c}-0.0976^{* *} \\
(0.0376)\end{array}$ & $\begin{array}{c}-0.1124^{* *} \\
(0.0519)\end{array}$ & $\begin{array}{c}-0.1035^{* *} \\
(0.0340)\end{array}$ \\
\hline FDI restrictions & $\begin{array}{c}-0.0668^{*} \\
(0.0356)\end{array}$ & $\begin{array}{c}-0.0750^{* *} \\
(0.0356)\end{array}$ & $\begin{array}{c}-0.0676^{*} \\
(0.0351)\end{array}$ & $\begin{array}{c}-0.0734^{* *} \\
(0.0339)\end{array}$ & $\begin{array}{c}-0.0728^{* *} \\
(0.0343)\end{array}$ & $\begin{array}{c}-0.0744^{* *} \\
(0.0350)\end{array}$ & $\begin{array}{c}-0.0768^{* *} \\
(0.0316)\end{array}$ \\
\hline Population under 14 & $\begin{array}{l}-0.0160 \\
(0.0102)\end{array}$ & $\begin{array}{c}-0.0164^{*} \\
(0.0091)\end{array}$ & $\begin{array}{c}-0.0161^{*} \\
(0.0089)\end{array}$ & $\begin{array}{c}-0.0167^{*} \\
(0.0092)\end{array}$ & $\begin{array}{l}-0.0149 \\
(0.0096)\end{array}$ & $\begin{array}{c}-0.0168^{*} \\
(0.0091)\end{array}$ & $\begin{array}{c}-0.0157^{*} \\
(0.0096)\end{array}$ \\
\hline Population over 65 & $\begin{array}{c}-0.0325^{*} \\
(0.0181)\end{array}$ & $\begin{array}{c}-0.3459^{*} \\
(0.0186)\end{array}$ & $\begin{array}{c}-0.0321^{*} \\
(0.0187)\end{array}$ & $\begin{array}{c}-0.0345^{*} \\
(0.0188)\end{array}$ & $\begin{array}{c}-0.0319^{*} \\
(0.0185)\end{array}$ & $\begin{array}{c}-0.0358^{*} \\
(0.0183)\end{array}$ & $\begin{array}{l}-0.0328^{*} \\
(0.0184)\end{array}$ \\
\hline Political risk & $\begin{array}{c}0.0103 \\
(0.0624)\end{array}$ & $\begin{array}{l}-0.0413 \\
(0.0461)\end{array}$ & & & & & \\
\hline Economic risk & $\begin{array}{l}-0.0802 \\
(0.0767)\end{array}$ & & $\begin{array}{l}-0.0910 \\
(0.0554)\end{array}$ & & & & \\
\hline Legal risk & $\begin{array}{c}0.0074 \\
(0.0677)\end{array}$ & & & $\begin{array}{l}-0.0475 \\
(0.0431)\end{array}$ & & & \\
\hline Tax risk & $\begin{array}{l}-0.0105 \\
(0.1077)\end{array}$ & & & & $\begin{array}{l}-0.0481 \\
(0.0588)\end{array}$ & & \\
\hline Operational risk & $\begin{array}{l}-0.0311 \\
(0.0993)\end{array}$ & & & & & $\begin{array}{r}-0.0684 \\
(0.0635)\end{array}$ & \\
\hline Security risk & & & & & & & $\begin{array}{c}-0.0846^{* *} \\
(0.0301)\end{array}$ \\
\hline Number of countries & 98 & 98 & 98 & 98 & 98 & 98 & 98 \\
\hline$R$-squared & 0.34 & 0.33 & 0.34 & 0.33 & 0.33 & 0.32 & 0.34 \\
\hline
\end{tabular}


TABle 6: Governance Indicators

Dependent variable Net FDI positions over GDP

\begin{tabular}{|c|c|c|c|c|c|c|}
\hline & $(1)$ & $(2)$ & $(3)$ & $(4)$ & $(5)$ & $(6)$ \\
\hline Constant & $\begin{array}{l}2.5294^{* *} \\
(0.7165)\end{array}$ & $\begin{array}{l}2.3439^{* *} \\
(0.7665)\end{array}$ & $\begin{array}{l}2.4514^{* *} \\
(0.7178)\end{array}$ & $\begin{array}{l}2.4396^{* *} \\
(0.7750)\end{array}$ & $\begin{array}{l}2.4062^{* *} \\
(0.7184)\end{array}$ & $\begin{array}{l}2.3516^{* *} \\
(0.7318)\end{array}$ \\
\hline Terrorist risk & $\begin{array}{c}-0.0027^{* *} \\
(0.0011)\end{array}$ & $\begin{array}{l}-0.0019 \\
(0.0022)\end{array}$ & $\begin{array}{c}-0.0026^{* *} \\
(0.0013)\end{array}$ & $\begin{array}{c}-0.0025^{* *} \\
(0.0012)\end{array}$ & $\begin{array}{c}-0.0026^{*} \\
(0.0015)\end{array}$ & $\begin{array}{l}-0.0027^{*} \\
(0.0014)\end{array}$ \\
\hline Log GDP per capita & $\begin{array}{c}-0.1164^{* *} \\
(0.0470)\end{array}$ & $\begin{array}{c}-0.1204^{* *} \\
(0.0460)\end{array}$ & $\begin{array}{c}-0.1119^{*} \\
(0.0566)\end{array}$ & $\begin{array}{c}-0.1166^{* *} \\
(0.0453)\end{array}$ & $\begin{array}{c}-0.1169^{* *} \\
(0.0518)\end{array}$ & $\begin{array}{l}-0.1074^{*} \\
(0.0572)\end{array}$ \\
\hline FDI restrictions & $\begin{array}{c}-0.0740^{*} \\
(0.0357)\end{array}$ & $\begin{array}{c}-0.0635^{*} \\
(0.0350)\end{array}$ & $\begin{array}{l}-0.0695 \\
(0.0420)\end{array}$ & $\begin{array}{c}-0.0709^{*} \\
(0.0411)\end{array}$ & $\begin{array}{c}-0.0658^{*} \\
(0.0374)\end{array}$ & $\begin{array}{l}-0.0695^{*} \\
(0.0390)\end{array}$ \\
\hline Corrected country risk & $\begin{array}{c}-0.1501^{* *} \\
(0.0670)\end{array}$ & $\begin{array}{c}-0.0862 \\
(0.0771)\end{array}$ & $\begin{array}{c}-0.1362 \\
(0.0961)\end{array}$ & $\begin{array}{l}-0.1237 \\
(0.0944)\end{array}$ & $\begin{array}{c}-0.1091 \\
(0.0730)\end{array}$ & $\begin{array}{c}-0.1183^{* *} \\
(0.0589)\end{array}$ \\
\hline Population under 14 & $\begin{array}{c}-0.0160^{*} \\
(0.0900)\end{array}$ & $\begin{array}{c}-0.0162^{*} \\
(0.0090)\end{array}$ & $\begin{array}{l}-0.0155 \\
(0.0094)\end{array}$ & $\begin{array}{c}-0.0155^{*} \\
(0.0089)\end{array}$ & $\begin{array}{c}-0.0159^{*} \\
(0.0091)\end{array}$ & $\begin{array}{l}-0.0149^{*} \\
(0.0094)\end{array}$ \\
\hline Population over 65 & $\begin{array}{c}-0.0299 \\
(0.0187)\end{array}$ & $\begin{array}{c}-0.3453^{*} \\
(0.0182)\end{array}$ & $\begin{array}{c}-0.0331^{*} \\
(0.0185)\end{array}$ & $\begin{array}{c}-0.0328^{*} \\
(0.0182)\end{array}$ & $\begin{array}{c}-0.0335^{*} \\
(0.0188)\end{array}$ & $\begin{array}{l}-0.0319^{*} \\
(0.0183)\end{array}$ \\
\hline \multicolumn{7}{|l|}{ Governance factors: } \\
\hline Voice and accountability & $\begin{array}{c}-0.0796 \\
(0.0620)\end{array}$ & & & & & \\
\hline Political stability & & $\begin{array}{c}0.0248 \\
(0.0709)\end{array}$ & & & & \\
\hline Government effectiveness & & & $\begin{array}{l}-0.0467 \\
(0.1268)\end{array}$ & & & \\
\hline Regulatory quality & & & & $\begin{array}{c}-0.0307 \\
(0.0811)\end{array}$ & & \\
\hline Rule of law & & & & & $\begin{array}{c}-0.0135 \\
(0.0839)\end{array}$ & \\
\hline Control of corruption & & & & & & $\begin{array}{r}-0.0390 \\
(0.0746)\end{array}$ \\
\hline Number of countries & 98 & 98 & 98 & 98 & 98 & 98 \\
\hline$R$-squared & 0.35 & 0.34 & 0.34 & 0.34 & 0.34 & 0.34 \\
\hline
\end{tabular}

Robust standard errors in parentheses.

** indicates statistical significance at the $5 \%$ level.

* indicates statistical significance at the $10 \%$ level.

All regressions include regional dummies. 
Table 7: Financial Factors, Macroeconomic Risk, and Natural Disasters Dependent variable Net FDI positions over GDP

\begin{tabular}{|c|c|c|c|c|c|}
\hline & (1) & $(2)$ & $(3)$ & (4) & $(5)$ \\
\hline Constant & $\begin{array}{l}3.2224^{* *} \\
(1.3752)\end{array}$ & $\begin{array}{c}2.5409^{*} \\
(1.4539)\end{array}$ & $\begin{array}{l}2.3820^{* *} \\
(0.7017)\end{array}$ & $\begin{array}{l}2.3129^{* *} \\
(0.7270)\end{array}$ & $\begin{array}{l}2.3275^{* *} \\
(0.7148)\end{array}$ \\
\hline Terrorist risk & $\begin{array}{l}-0.0023^{*} \\
(0.0014)\end{array}$ & $\begin{array}{l}-0.0021 \\
(0.0019)\end{array}$ & $\begin{array}{c}-0.0025^{* *} \\
(0.0012)\end{array}$ & $\begin{array}{c}-0.0025^{* *} \\
(0.0012)\end{array}$ & $\begin{array}{c}-0.0024^{* *} \\
(0.0012)\end{array}$ \\
\hline Log GDP per capita & $\begin{array}{l}-0.0593 \\
(0.0682)\end{array}$ & $\begin{array}{l}-0.0658 \\
(0.1024)\end{array}$ & $\begin{array}{c}-0.1192^{* *} \\
(0.0484)\end{array}$ & $\begin{array}{c}-0.1130^{* *} \\
(0.0484)\end{array}$ & $\begin{array}{c}-0.1156^{* *} \\
(0.0459)\end{array}$ \\
\hline FDI restrictions & $\begin{array}{l}-0.0806^{*} \\
(0.0440)\end{array}$ & $\begin{array}{c}-0.0965^{*} \\
(0.0583)\end{array}$ & $\begin{array}{l}-0.0570 \\
(0.0361)\end{array}$ & $\begin{array}{c}-0.0629^{*} \\
(0.0355)\end{array}$ & $\begin{array}{l}-0.0676^{*} \\
(0.0356)\end{array}$ \\
\hline Corrected Country Risk & $\begin{array}{l}-0.0989 \\
(0.1100)\end{array}$ & $\begin{array}{c}0.0306 \\
(0.1320)\end{array}$ & $\begin{array}{c}-0.1131^{*} \\
(0.0594)\end{array}$ & $\begin{array}{l}-0.1045 \\
(0.0646)\end{array}$ & $\begin{array}{r}-0.0926 \\
(0.0601)\end{array}$ \\
\hline Population under 14 & $\begin{array}{c}-0.0097 \\
0.0095\end{array}$ & $\begin{array}{c}-0.0336^{*} \\
(0.0192)\end{array}$ & $\begin{array}{c}-0.0162^{*} \\
(0.0093)\end{array}$ & $\begin{array}{l}-0.0157 \\
(0.0095)\end{array}$ & $\begin{array}{l}-0.0155^{*} \\
(0.0090)\end{array}$ \\
\hline Population over 65 & $\begin{array}{c}-0.0251 \\
(0.0205)\end{array}$ & $\begin{array}{c}-0.0666^{* *} \\
(0.0264)\end{array}$ & $\begin{array}{c}-0.0356^{*} \\
(0.0186)\end{array}$ & $\begin{array}{c}-0.0333^{*} \\
(0.0184)\end{array}$ & $\begin{array}{l}-0.0329^{*} \\
(0.0188)\end{array}$ \\
\hline Credit (over GDP) & $\begin{array}{c}-0.1859 \\
(0.1423)\end{array}$ & & & & \\
\hline Real eff. X-rate range & & $\begin{array}{l}-0.0028 \\
(0.0031)\end{array}$ & & & \\
\hline Gov. cons. (over GDP) & & & $\begin{array}{c}0.0021 \\
(0.0063)\end{array}$ & & \\
\hline Std. Dev. growth rate & & & & $\begin{array}{c}0.0332 \\
(0.0184)\end{array}$ & \\
\hline Earthquake risk index & & & & & $\begin{array}{l}-0.0092^{*} \\
(0.0049)\end{array}$ \\
\hline Number of countries & 71 & 55 & 97 & 97 & 98 \\
\hline$R$-squared & 0.38 & 0.50 & 0.35 & 0.34 & 0.34 \\
\hline
\end{tabular}

Robust standard errors in parentheses.

** indicates statistical significance at the $5 \%$ level.

* indicates statistical significance at the $10 \%$ level.

All regressions include regional dummies. 
$\underline{186 \text {-country sample }}$

Afghanistan, Algeria, Andorra, Angola, Bahrain, Bangladesh, Barbados, Belgium, Belize, Benin, Bermuda, Bhutan, Brazil, Brunei, Burkina Faso, Burundi, Cameroon, Cayman Islands, Central African Republic, Chad, Chile, China, Colombia, Congo, Cote d'lvoire, Cuba, Cyprus, DRCongo, East Timor, Equatorial Guinea, Ethiopia, Fiji, French Guiana, Gabon, Grenada, India, Iran, Iraq, Israel, Kazakhstan, Kuwait, Lao PDR, Libya, Liechtenstein, Luxembourg, Macau, Madagascar, Mali, Malta, Martinique, Moldova, Mozambique, Myanmar (Burma), Namibia, Nepal, Niger, Nigeria, North Korea, Oman, Puerto Rico, Qatar, Russia, Rwanda, Samoa, Saudi Arabia, Senegal, Somalia, Sri Lanka, Suriname, Syria, Taiwan, Tanzania, Togo, United Arab Emirates, Uzbekistan, Zimbabwe, plus those countries in the 110-country sample.

\section{0-country sample}

Antigua and Barbuda, Comoros, Dominica, Eritrea, Liberia, Maldives, Palestinian Authority, Papua New Guinea, Sao Tome, Serbia and Montenegro, Seychelles, Sudan, plus those countries in the 98-country sample.

\section{8-country sample}

Albania, Argentina, Armenia, Australia, Austria, Azerbaijan, Bahamas, Belarus, Bolivia, Bosnia and Herzegovina, Botswana, Bulgaria, Cambodia, Canada, Cape Verde, Costa Rica, Croatia, Czech Republic, Denmark, Djibouti, Dominican Republic, Ecuador, Egypt, El Salvador, Estonia, Finland, France, Gambia, Georgia, Germany, Ghana, Greece, Guatemala, Guinea, Guinea Bissau, Guyana, Haiti, Honduras, Hong Kong SAR, Hungary, Iceland, Indonesia, Ireland, Italy, Jamaica, Japan, Jordan, Kenya, Kyrgyzstan, Latvia, Lebanon, Lesotho, Lithuania, Macedonia, Malawi, Malaysia, Mauritania, Mauritius, Mexico, Mongolia, Morocco, Netherlands, New Zealand, Nicaragua, Norway, Pakistan, Panama, Paraguay, Peru, Philippines, Poland, Portugal, Romania, Sierra Leone, Singapore, Slovakia, Slovenia, South Africa, South Korea, Spain, Swaziland, Sweden, Switzerland, Tajikistan, Thailand, Trinidad and Tobago, Tunisia, Turkey, Turkmenistan, Uganda, Ukraine, United Kingdom, United States, Uruguay, Venezuela, Vietnam, Yemen and Zambia. 